\title{
Recovery Plan for Monilinia polystroma Causing Asiatic Brown Rot of Stone Fruit
}

Updated March 2018

K. D. Cox, ${ }^{\dagger}$ Plant Pathology and Plant-Microbiology Section, Cornell University, Geneva, NY 14456; S. M. Villani, Department of Entomology and Plant Pathology North Carolina State University, Mills River, 28759; Anna Poniatowska, Department of Plant Pathology, Research Institute of Horticulture, 96-100 Skierniewice, Poland; Guido Schnabel, Department of Agricultural \& Environmental Sciences, Clemson University, Clemson, SC 29634; Imre Holb, Faculty of Agricultural and Food Sciences and Environmental Management, Institute of Horticulture, University of Debrecen, H-4015 Debrecen, Hungary; and Julius Fajardo, USDA-Office of Pest Management Policy, Washington, DC 20250.

Accepted for publication 12 March 2018.

Table of Contents

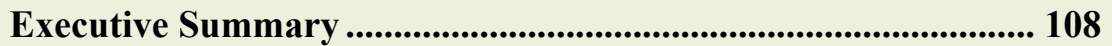

I. Introduction ............................................................................... 109

II. Disease Development: Symptoms and Signs..............................110

III. Spread and Risk Map......................................................................113

IV. Permits and Regulations........................................................115

V. Diagnostics and Identification .................................................115

VI. Mitigation and Disease Management .......................................117

VII. Economic Impact........................................................................... 120

VIII. Response ............................................................................... 121

IX. Research, Education, and Extension Priorities........................ 122

X. References ........................................................................... 122

${ }^{\dagger}$ Chair and corresponding author: K. D. Cox; E-mail: kdc33@cornell.edu

This article is in the public domain and not copyrightable.

It may be freely reprinted with customary crediting of the source.

The American Phytopathological Society, 2018. 
This recovery plan is one of several disease-specific documents produced as part of the National Plant Disease Recovery System (NPDRS) called for in Homeland Security Presidential Directive Number 9. The purpose of the NPDRS is to ensure that the tools, infrastructure, communication networks, and capacity required to mitigate the impact of high-consequence plant disease outbreaks can maintain a reasonable level of crop production.

Each disease-specific plan is intended to provide a brief primer on the disease, assess the status of critical recovery components, and identify disease management research, extension, and education needs. These documents are not intended to be standalone documents that can address all of the many and varied aspects of plant disease outbreak and all of the decisions that must be made and actions taken to achieve effective response and recovery. They are, however, documents that will help USDA guide further efforts directed toward plant disease recovery.

\section{Executive Summary}

Stone fruit is an economically important group of specialty fruit crops in the United States valued at approximately $\$ 4.4$ billion in annual total utilized production. Brown rot of stone fruit is one of the most important stone fruit diseases worldwide. The disease can affect several host tissues, and specific disease names are often ascribed to the type of host tissue affected. These include blossom blight, shoot blight, fruit blight, and brown fruit rot. The type of disease and symptoms observed are highly dependent on the stone fruit host and the species of the pathogen causing the infection. Brown rot of stone fruit is caused by fungal species in the genus Monilinia. The most common species causing brown rot worldwide include Monilinia fructicola, M. laxa, and M. fructigena. In addition, there are several minor species including M. mumecola, M. yunnanensis, and $M$. polystroma that are known to cause brown rot of stone fruit in Central Europe and Asia. Of the aforementioned species, M. yunnanensis and M. polystroma were both initially misclassified as M. fructigena. M. polystroma, in particular, is highly similar to M. fructigena in terms of its pathobiology, but is slightly less aggressive and less prevalent. Presently, M. polystroma has only been reported in Asia and Central Europe. Neither M. polystroma, the causal agent of "Asiatic brown rot", nor M. fructigena, one of the causal agents of "European brown rot", have been reported in North America. However, both M. polystroma and M. fructigena can also cause brown rot of apple, a fruit crop that is densely planted in the eastern United States. The density of acreage planted to susceptible hosts, combined with the proximity of international ports of entry, places the pome and stone fruit industries of the eastern United States at the highest risk of introduction of these two species.

Species of Monilinia can be differentiated on the basis of cultural morphology and growth. Such methods can have some level of subjective interpretation, and variability among strains can lead to difficulties in species differentiation under all but the most controlled conditions. Monilinia species can be more objectively and reliably distinguished from one another using genetic methods. Numerous protocols are available for identifying microbial species directly from infected host tissues or from isolated cultures.

Management of brown rot is primarily achieved through the use of fungicides and to a lesser extent, sanitation. Applications of fungicides begin at bloom to control the blossom blight stage of this pathogen, and to manage species like M. laxa, which prefer colder climates and preferentially infect flowers and shoots. Fungicides are applied from early fruit development through harvest for species that also cause preharvest fruit rots, such as M. fructicola, M. fructigena, and M. polystroma. Postharvest fungicide drenches in packinghouses and controlled atmospheric storage are used to further minimize the incidence of brown fruit rot. 
M. polystroma and closely related species like M. fructigena are invasive plant pathogens, and import regulations should prevent the entry of infected pome and stone fruit materials. Formal efforts may be needed to screen imported apple and stone fruit tissues for latent infections that may emerge after materials are disseminated. Should M. polystroma become established in North America, it is likely that the species will not create management problems beyond what growers are faced with today, or may not even persist owing to a combination of competition with $M$. fructicola and routine fungicide applications made to manage endemic Monilinia species. The best course of action for managing this threat will involve a combination of exclusion through legislative quarantines, early detection, and eradication by fungicides and potentially host destruction.

\section{Introduction}

M. polystroma (van Leeuwen) is a newly identified species in the genus Monilinia and has been reported to cause blossom blight and brown fruit rot in stone fruit and apple in Europe. In some regions, including North America, the disease is commonly referred to as Asiatic brown rot; however, the disease is essentially no different than what is traditionally referred to as brown rot of stone fruit caused by various Monilinia species. Brown rot occurs worldwide, and M. polystroma was just one of the species causing brown rot in Japan when it was first discovered there in the late 1970s. For some time, the pathogen was designated by the anamorph name Monilia polystroma. However, the teleomorph of this fungus was produced in vitro by Harada (1977), at a time when it was classified as M. fructigena, and Johnston et al. (2014) proposed the genus Monilinia despite the absence of a naturally occurring teleomorph. Hence, in this document, we will refer to this species as a member of the genus Monilinia. Although many Central European countries, including Hungary and Poland, have had reoccurring brown rot epidemics in stone fruit and apples since the 1970s, it was not until the turn of the 21 st century that $M$. polystroma was differentiated from M. fructigena, one of the other endemic European species of Monilinia (Fulton et al. 1999; Poniatowska et al. 2016; van Leeuwen et al. 2002a). It is hypothesized that international trade of stone fruit within and across the continents led to the spread and establishment of M. polystroma in Asia and Europe (Poniatowska et al. 2016).

Stone fruits are important specialty crops in the United States. Cherries and peaches are the most widely planted stone fruit, planted to approximately 330,000 acres and valued at approximately US\$4.4 billion annually (USDA National Agricultural Statistics Service 2016). East of the Mississippi River, stone fruit production is highest in Michigan, South Carolina, Georgia, and New Jersey. Apples are a similarly important specialty fruit crop, planted to approximately 250,000 acres and valued at approximately US $\$ 3.3$ billion annually (USDA National Agricultural Statistics Service 2016). East of the Mississippi River, apple production is highest in New York, Michigan, and Pennsylvania. Given the high value of these specialty crops, invasive species of $\mathrm{Mo}$ nilinia should be of concern.

In the United States, brown rot is an endemic disease that affects all stone fruit production, but it is most devastating in the temperate stone fruit production regions in the eastern United States and around the Great Lakes. In these regions, rainfall is abundant throughout the growing season, mandating the use of regular fungicide applications from bud break to harvest. Even in orchards managed with conventional fungicides, the incidence of preharvest brown rot may exceed 5\%, especially in regions where populations of $M$. fructicola have resistance to one or more classes of fungicides (Hily et al. 2011; Villani and Cox 2011).

There are two endemic species of Monilinia in North America that attack stone fruit and apples. The most prevalent species is M. fructicola, which is primarily responsible for brown rot epidemics in stone fruit and apples throughout the United States. M. laxa, 
commonly referred to as the pathogen of European brown rot, is also present in North America but is less prevalent in stone fruit. M. laxa primarily causes blossom and shoot blight in almonds, apricots, and cherries in the western United States (Ogawa and English 1991), and blossom and shoot blight of cherries, nectarines, and apricots in Michigan, New York, and Rhode Island (Cox et al. 2011; Cox and Villani 2010; Jones and Aldwinkle 1990). This species is believed to have been imported on nursery stock of European stone fruit varieties during the establishment of the stone fruit industry in the eastern and western United States (Ogawa and English 1991).

In Europe, M. laxa and M. fructigena are the two most prevalent species, with $M$. fructicola considered as invasive to the continent, likely introduced from North America. With the advent of accessible molecular diagnostic techniques, it became apparent that regional differences in morphology for $M$. fructigena were actually indicative of different species. Fulton et al. (1999) found that " $M$. fructigena" from Japan differed from M. fructigena from Europe by 5 base pairs in the internal transcribed spacers (ITS1 and ITS2) of the rDNA gene cluster. Shortly afterward, van Leeuwen et al. (2002a) fully described the morphological differences between $M$. fructigena and what they defined as a new species, M. polystroma. With the increased international trade resulting from expansion of stone fruit industries in Central European countries such as Poland and Hungary, M. polystroma became more prevalent in that region and has been detected in the Czech Republic, Italy, Serbia, Croatia, and Switzerland (Petróczy and Palkovics 2009; Poniatowska et al. 2016). By 2015, several comprehensive phylogenetic analyses and pathogenicity studies had better defined the pathobiology of this newly discovered Monilinia species (Poniatowska et al. 2016; Vasić et al. 2016). As international trade and interest in European stone fruit and apples increase in the coming years, the risk of global spread of M. polystroma becomes more probable. Hence, an action plan is needed to better understand and meet the challenges of this newly identified species.

\section{Disease Development: Symptoms and Signs}

Monilinia species, including M. polystroma, cause blossom blight, shoot blight, fruit blight, and brown fruit rot of mature and immature stone fruit. Like other species of Monilinia, M. polystroma overwinters in shoot cankers that are the result of visible or quiescent shoot infections from previous seasons, and in mummified fruitlets on the orchard floor (Jones and Aldwinckle 1990; van Leeuwen et al. 2002a) (Fig. 1). Infected cankers and mummified fruit sporulate and produce conidia in the spring as temperatures warm (Fig. 1). Conidia produced on these host tissues are then dispersed during subsequent precipitation events, thus spreading to young shoots and flowers when buds break and spring growth begins. Apothecia are rarely observed on mummified fruit in
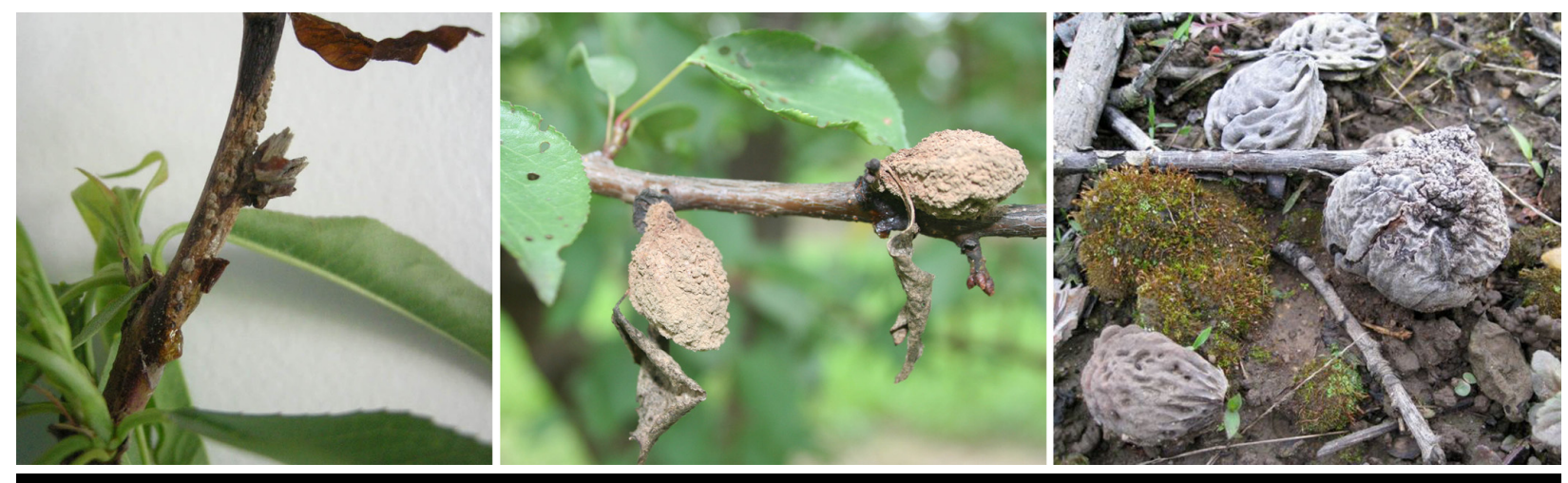

FIGURE 1

Overwintering shoot cankers on peaches sporulating with Monilinia conidia in the spring after vegetative bud break (left). Mummified fruit of apricots sporulating with Monilinia conidia on trees at the end of the season (middle), and mummified peach fruit on the ground in the spring after snow melt (right). 
stone fruit orchards, and M. polystroma apothecia have only been produced in laboratory conditions (Harada 1977; Jones and Aldwinckle 1990). Hence, ascospores likely contribute little to disease development.

M. polystroma is reported as causing shoot and blossom blight, and in this regard, infections by conidia typically occur in cool, wet weather shortly after flower and vegetative buds break and begin to grow (Fig. 2). Young emerging shoots have few natural
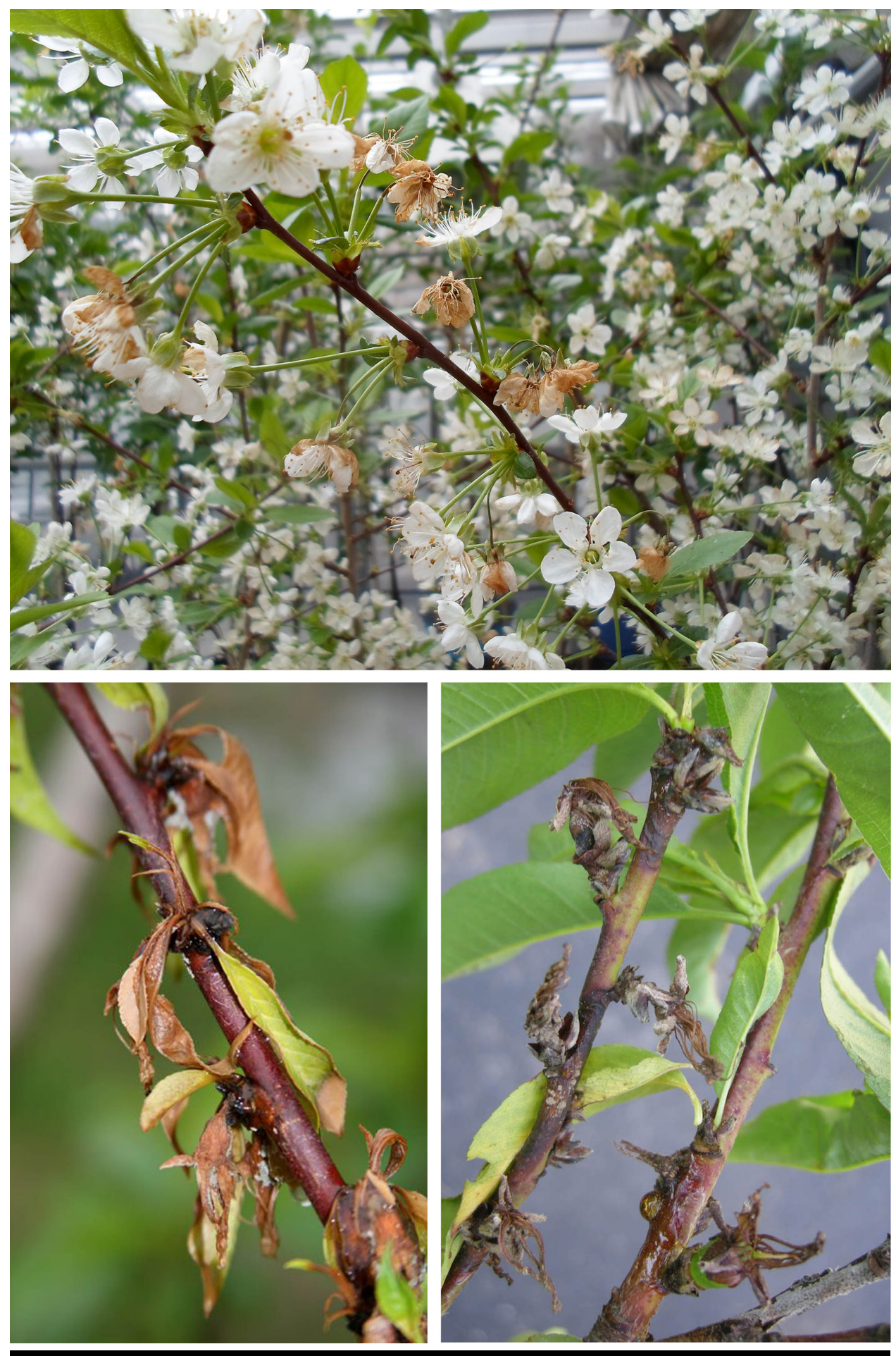

FIGURE 2

Blossom blight of sour cherry caused by Monilinia polystroma in Poland (top). Blighted flower and vegetative buds on apricots (bottom left), and blighted blossoms and immature green fruit after shuck off in nectarine caused by $M$. laxa (bottom right). 
plant defenses and newly opening flowers are rich in sugars, making them susceptible to brown necrotic blight, which can be quite extensive under prolonged wetting periods. Following infection, young vegetative shoots, leaf buds, and flower buds become wilted and develop a brown necrosis that spreads from the point of infection. If the weather remains cool and wet, the infection will spread and encompass the developing bud, open flower, and potentially the developing shoot, which in turn will lead to further sporulation with tufts of grayish/tan conidia. These can cause additional secondary infections of newly opened flowers, which will also become blighted and lead to subsequent infection of young developing fruit.

Shortly after petal fall, the sepals of stone fruit will split, and the papery remnants of petals will dry up and fall away, revealing young green immature fruit (Fig. 2). At this stage of "shuck split" or "shuck off", the immature fruit are highly susceptible to infections from conidia produced previously on blossoms and blighted shoots. Given the low sugar content of these fruit, infections may remain latent until sufficient levels of sugars accumulate during fruit maturation or postharvest to support invasion of the fruit mesocarp tissues (Luo and Michailides 2001; Luo et al. 2005).

In the absence of cool, wet weather during bud break and bloom, overwintering cankers and mummified fruit may sporulate and produce conidia in late spring and early summer, which will then infect fruit as they mature and increase in sugar content (Fig. 3). Monilinia sp. are necrotrophic pathogens, and infections typically occur at sites of wounding caused by rubbing from wind, rain cracking, insects and birds, or other mechanical injury associated with production practices. Infections may occur by direct penetration using appressoria, but these occur to a lesser extent and are primarily involved in latent infections. Initial infections will begin as small, light brown, watersoaked lesions that expand with mycelial invasion and turn darker at the center of the original point of infection. As nutrients are used up in the older infected tissues, the fungus will initiate clonal reproduction and sporulate, producing characteristic gray/tan tufts of conidia. The continual expansion of invading mycelia and the exhaustion of available nutrients will often lead to concentric rings of sporulation. Stone fruit with a high sugar content and low numbers of protective trichomes on the exocarp (e.g., sweet cherries and nectarines) are more susceptible to infection as harvest approaches. Preharvest infections may also remain latent and emerge postharvest in storage, causing considerable fresh market losses.

In general, apples are more resilient to infection by Monilinia species owing to a thick waxy cuticle over the exocarp and an extremely firm mesocarp. Infections are typically initiated by conidia produced in the spring from overwintering cankers in nearby stone fruit plantings and potentially from apple mummies remaining in the trees
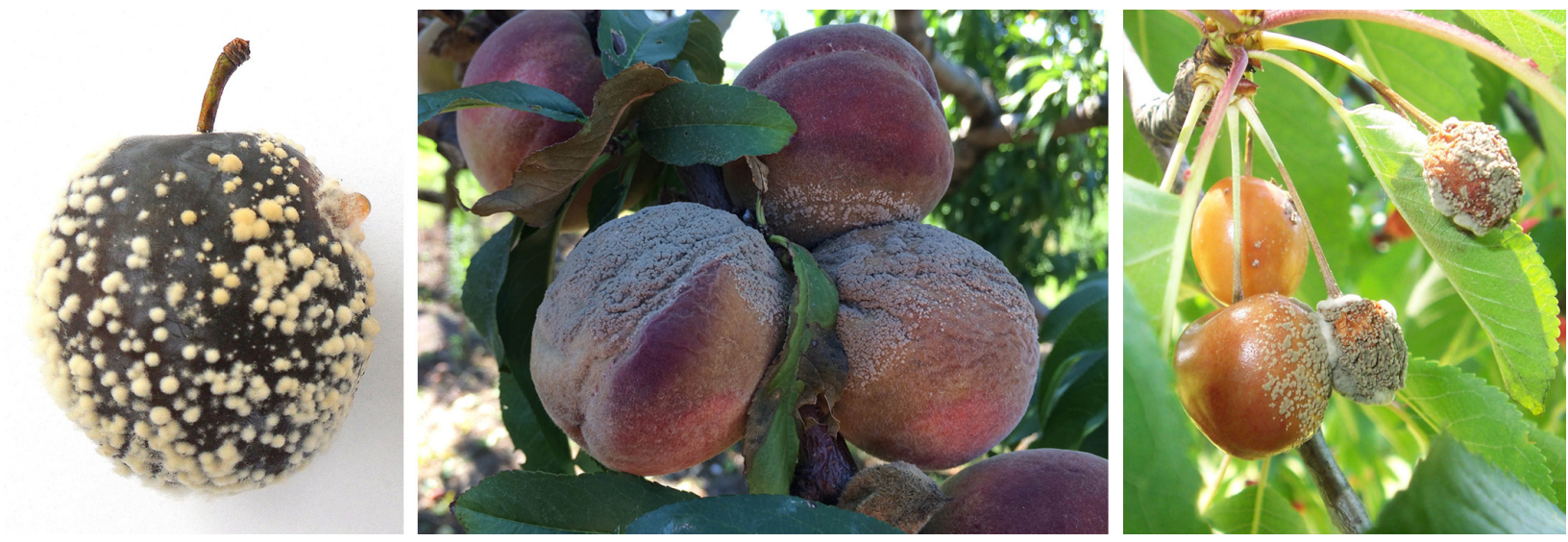

FIGURE 3

Preharvest brown fruit rot with conidial sporulation of Monilinia polystroma on plum in Poland (left). Preharvest brown fruit rot with conidial sporulation M. fructicola on peach (middle) and on sweet cherry (right). 
after harvest (Fig. 4). Infection of apple blossoms and shoots is rarely reported for Monilinia sp. However, in Hungary, M. polystroma was observed to blight fruit clusters in 'Ashton Bitter' apples (Petróczy and Palkovics 2009). These infections produced a pale brown, necrotic blight of petioles, pedicles, and young fruitlets that were covered in yellowish stromata.

Aside from the above example, infections of apple and pear fruit usually occur from late summer to fall as fruit begin to mature, convert starch to sugar, and mesocarp tissues begin to soften (Holb and Scherm 2008) (Fig. 4). Because apple fruit have a thick waxy cuticle, infection often occurs through a wound caused by insects, rubbing against objects, or birds. There have been reports, however, of late harvest brown rot epidemics in apples in which wounding was not always observed (Beckerman et al. 2016). Similar to stone fruit, infections of apples and pears by M. polystroma begin as small light brown, water-soaked lesions that expand as the infection develops. The older portions of the lesion will darken and sporulate as sugars are used up and the fungus continuously invades healthy sections of the mesocarp. As with stone fruit, latent infections may be present that only become apparent after harvest (Vasić et al. 2016). Mycelial invasion of fruit tissues is more easily accomplished after harvest when ethylene production accelerates fruit ripening and sugary mesocarp tissues soften. Indeed, the ectoand endostroma produced by $M$. polystroma potentially allow the fungus to survive at lower temperatures, because it is more frequently isolated from apples in cold storage $\left(4\right.$ to $5^{\circ} \mathrm{C}$ ) compared with $M$. fructigena, which grows more poorly in cold temperatures (Vasić et al. 2016).

\section{Spread and Risk Map}

Within orchards, M. polystroma is primarily dispersed as conidia, sporulating on overwintering cankers, mummies, and on current-year infected tissues. Apothecia of $M$. polystroma have not been observed in apple or stone fruit orchards, and ascospores likely contribute little to the spread of the pathogen within orchards or over long distances. Although insects have been shown to spread conidia of $M$. fructigena (Lack 1989), the importance of insects in the spread of brown rot and M. polystroma is not well known. The establishment of M. polystroma in new orchards and new countries is likely accomplished through the movement of propagation material or nursery stock with latent bud infections or overwintering cankers small enough to go unnoticed by inspectors. Indeed, this has been postulated by Poniatowska et al. (2016) and in several

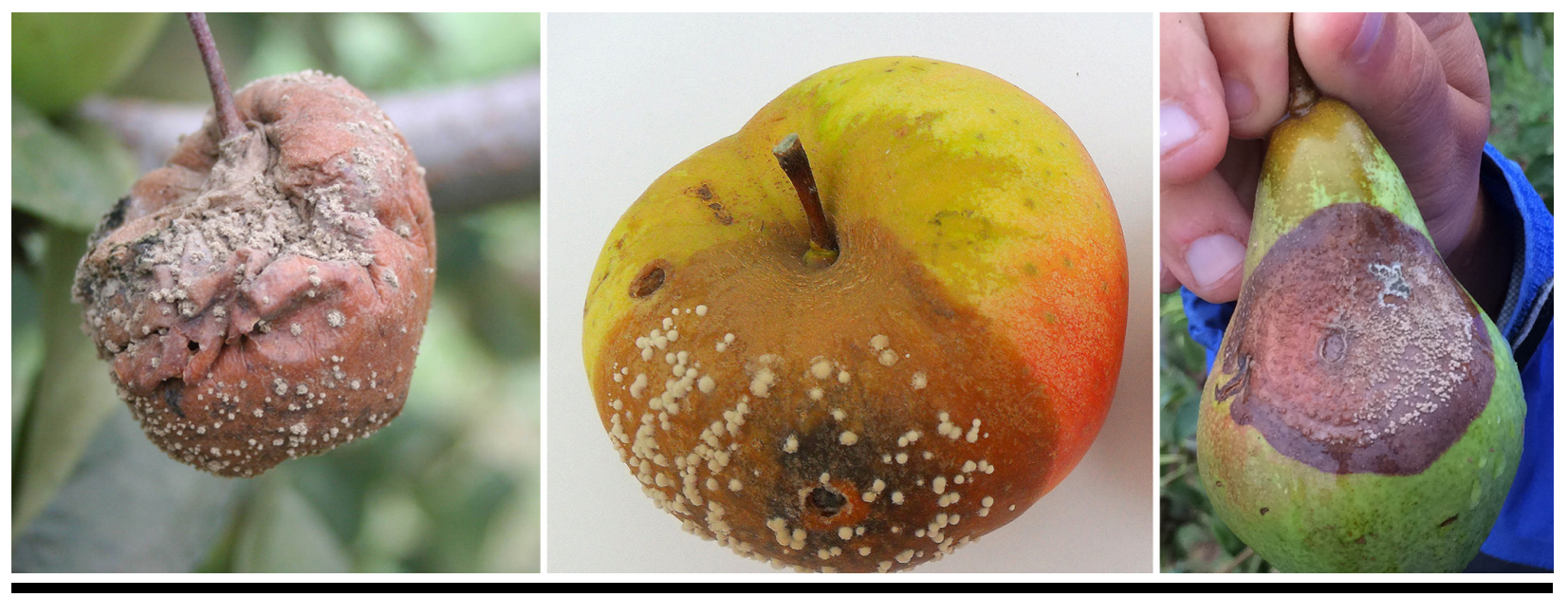

\section{FIGURE 4}

Sporulation on mummified apple fruit infected with Monilinia fructicola in late August in an orchard on Long Island, NY (left). Sporulating, preharvest brown rot lesions caused by M. polystroma on an apple from Poland (middle). Sporulation on a pear infected with M. fructicola in an orchard from Long Island, NY (right). 
of the recent reports on the pathogen's detection in Europe (Petróczy and Palkovics 2009; Vasić et al. 2013, 2016). Although it is possible that M. polystroma could be transported as latent infections on seemingly healthy fruit sold to commercial outlets, it is unlikely that such fruit would be transported to apple or stone fruit production operations where it would pose the greatest threat. Hence, imported fresh market fruit infected with M. polystroma is unlikely to be a source for establishing this pathogen in new regions. That being said, diseased or symptomatic fruit from production regions known to have M. polystroma should still be quarantined and tested for the presence of M. polystroma to minimize any risk of ingress to other continents. Currently, stone fruit imports occur primarily from Chile in the winter months, and more stone fruit is imported than pome fruit (Anonymous 2016a, b). There have been no reports of invasive Monilinia sp. in Chile. Hence, such quarantine would only likely be enforced on small shipments of imported apple fruit from EU countries (Anonymous 2016a) when domestic production is too low to satisfy consumer demand.

As mentioned previously, M. polystroma is a species native to Japan that morphologically closely resembles one of the more prevalent European species, M. fructigena. It is likely that M. polystroma was present in Europe for some time prior to its discovery but was only more recently detected owing to the development of molecular diagnostics and the establishment of active applied research programs in the Netherlands, Hungary, Poland, and Serbia. M. polystroma was first detected in 2009 in Hungary on apples (Petróczy and Palkovics 2009) and afterward on apple, pear, and plum in China in 2010

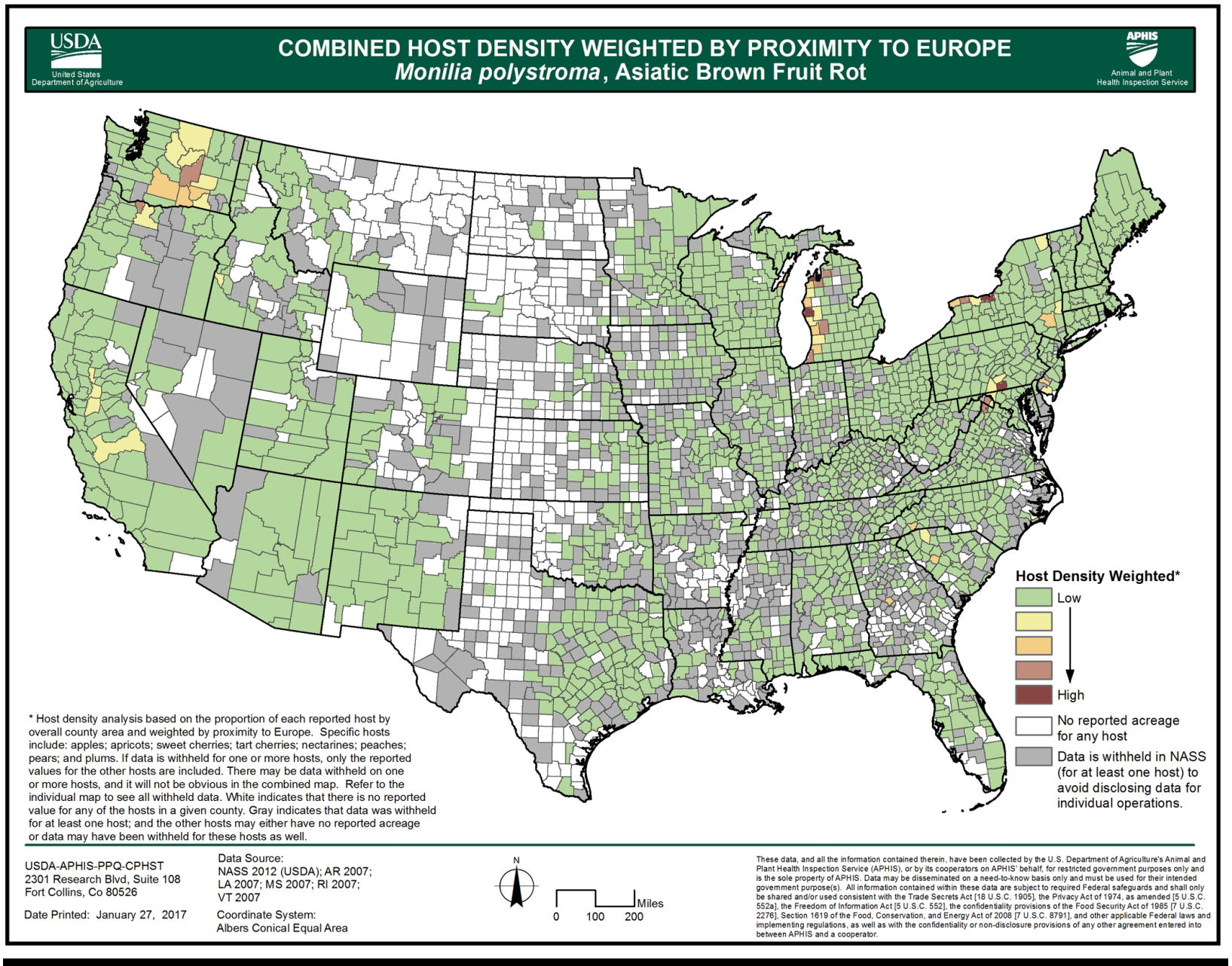

FIGURE 5

Map developed by USDA-APHIS-PPQ-CPHST indicating the potential risk and economic impact of Monilinia polystroma based on host acreage for apple and stone fruit and proximity to European import markets. 
(Zhu and Guo 2010), on apple and peach in the Czech Republic in 2011 (Anonymous 2011), on apricot in Switzerland in 2012 (Hilber-Bodmer et al. 2012), on apple in Serbia in 2013 (Vasić et al. 2013), on apple, peach, plum, and cherry in Poland in 2013 (Poniatowska et al. 2016), on peach in Italy in 2014 (Martini et al. 2014), on apples in Croatia in 2015 (Di Francesco et al. 2015), and on peach in Slovenia in 2011 (Munda 2015). To date, M. polystroma has not been discovered in any of the European countries bordering the Atlantic ocean including France, Spain, Portugal, and the United Kingdom. The worldwide prevalence of M. polystroma is being monitored by the European and Mediterranean Plant Protection Organization (EPPO). The most current information on the distribution of $M$. polystroma can be found in their public database (https://gd.eppo.int/taxon/MONIPO/). Although there have been no reports of M. polystroma in North America to date, there have been numerous efforts to prepare this continent for this invasive brown rot species. Indeed, there have been several excellent fact sheet resources produced by the USDA-ARS and New York State IPM on M. polystroma and M. fructigena (NYS fact sheet, Sullivan 2013). In 2012, New York State participated in a USDA APHIS Cooperative Agricultural Pest Survey (CAPS) for $M$. polystroma in New York. The outcome of the survey indicated that neither M. polystroma nor M. fructigena were present in any of the apple and stone fruit orchards surveyed. In addition to these resources, USDA-APHIS-PPQ-CPHST developed a risk map for M. polystroma in 2010 through the NAPPFAST organization (Fig. 5). The risk map accounts for the host acreage density for apple and stone fruit, and proximity to ports of entry. Although the hosting site for the map is no longer available, the map remains a useful tool for predicting the risk of impact for M. polystroma.

\section{Permits and Regulations}

Presently, M. polystroma is neither listed as a select agent on the USDA/APHIS select agent and toxin list nor listed as a regulated plant pest by USDA/APHIS (https:// www.aphis.usda.gov/import_export/plants/plant_imports/downloads/RegulatedPest List.pdf). The list of regulated plant pests is composed of pests and pathogens that represent quarantine concerns owing to their potential to cause considerable economic or environmental harm as described in 7 CFR Part 331 of the 2002 Agricultural Bioterrorism Protection Act (Cline and Farr 2006). Although M. polystroma is not currently on the list, the closely related $M$. fructigena is a regulated pathogen. Because M. polystroma is so similar to $M$. fructigena in terms of its pathobiology, its inclusion in future revisions to the regulated plant pest list should be considered. Despite its regulatory status, M. polystroma still falls under the Plant Protection Act (7 CFR Part 330), which mandates that USDA/APHIS PPQ permits (https://www.aphis.usda.gov/aphis/resources/ permits) would be required for interstate or international movement of infected apple or stone fruit plant material. This USDA/APHIS PPQ regulatory barrier should be sufficient to protect against entry of $M$. polystroma on imported plant material and subsequent interstate spread. Additionally, any imported plant material infected with $M$. polystroma would likely be misidentified as M. fructigena on initial inspection and be flagged as a USDA/APHIS regulated plant pest, thereby preventing entry into the United States until further testing was completed.

\section{Diagnostics and Identification}

Historically, the identification of Monilinia spp. was accomplished on the basis of cultural characteristics, morphological traits, and growth pattern (Fig. 6). Indeed, the current CAPS approved methodology for M. polystroma is based on morphological identification until CPHST Beltsville fully evaluates the available molecular-based methods used in academia to differentiate Monilinia species. The CAPS-approved methodology recommends identification on the basis of growth pattern, growth rate, 
conidial size, and germ tube length as described by van Leeuwen and van Kesteren (1998) and De Cal and Melgarejo (1999). Morphological differentiation can be supplemented using the characters described by Lane (2003) for distinguishing M. laxa from M. fructicola, and those described by van Leeuwen et al. (2002a) for M. polystroma.

Species identification on the basis of morphology and growth alone can have some level of subjectivity, and variability among strains can lead to difficulties in species

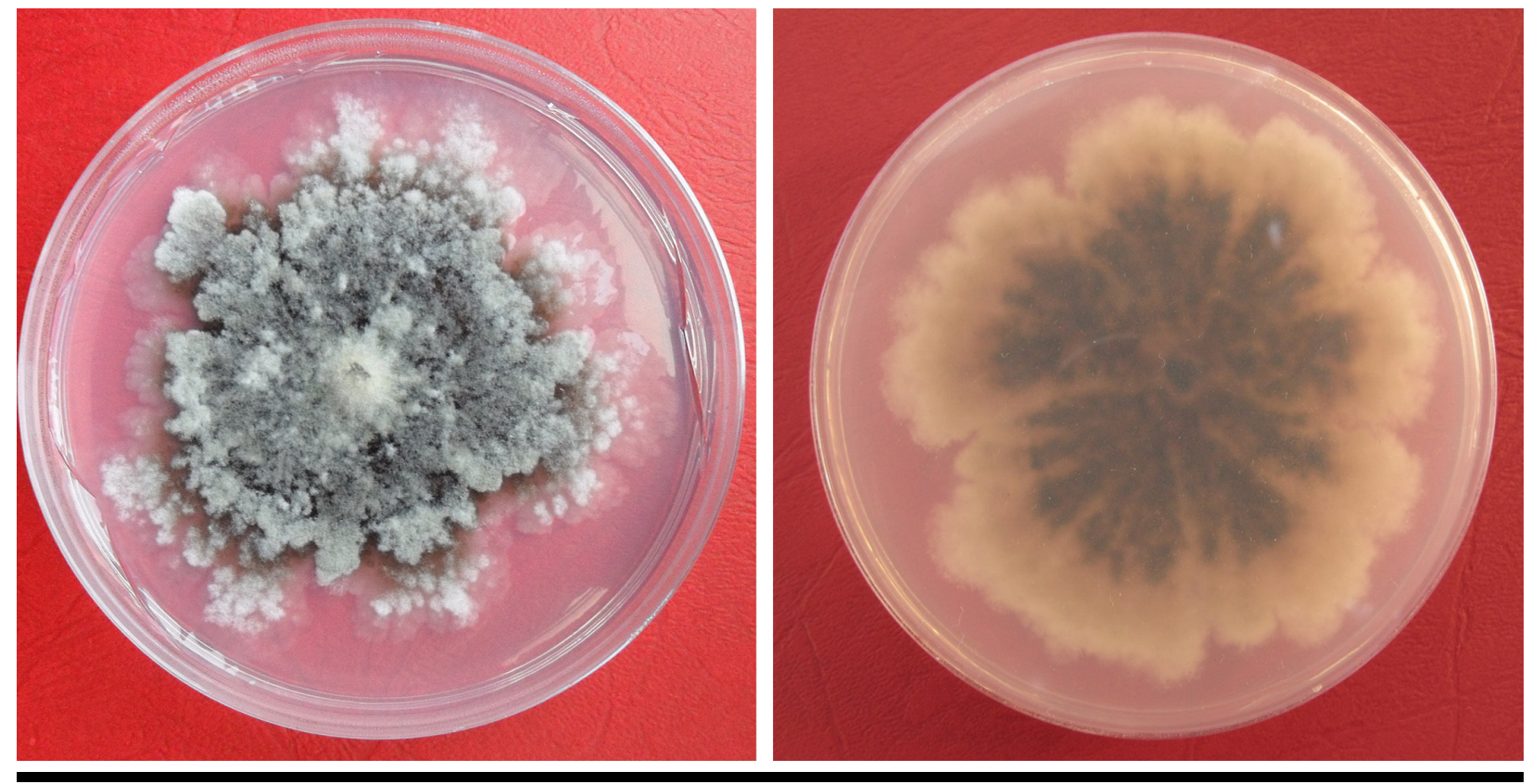

FIGURE 6

Seven-day-old cultures of Monilinia polystroma on potato dextrose agar medium displaying the characteristic lobed stromata formation on the undersurface of the colony (left), which is more visible on the reverse (right).

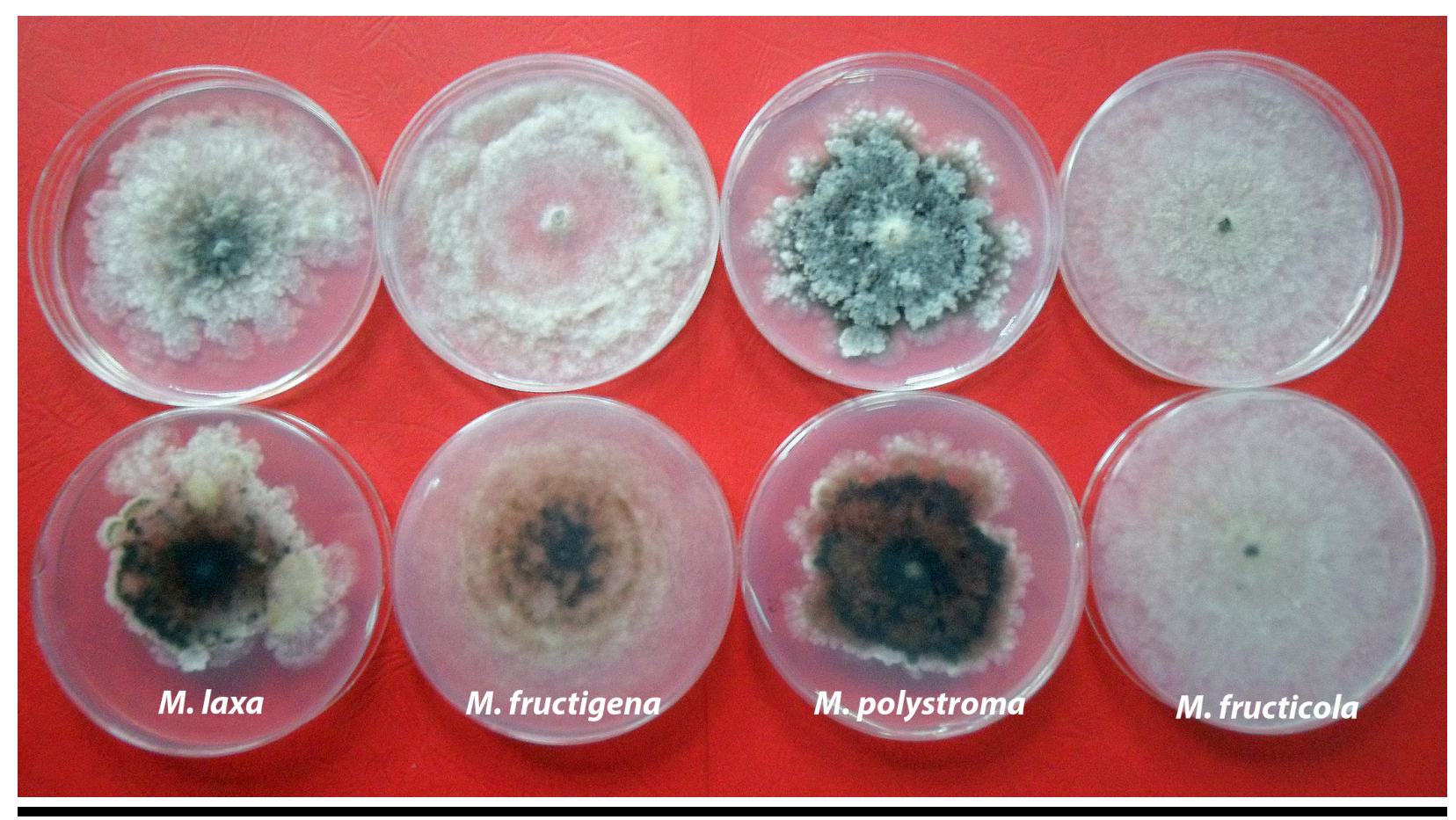

\section{FIGURE 7}

Morphological differences between cultures of Monilinia polystroma, M. fructicola, M. fructigena, and M. laxa incubated for 7 days on potato dextrose agar medium at $22^{\circ} \mathrm{C}$ in 12 -h near-UV light/dark cycles. Note the diagnostic presence of excessive stromata in the cultures of $M$. polystroma. 
differentiation under all but the most controlled conditions (Fig. 7). Indeed, the authors of this document have observed that changes in laboratory conditions and slight differences in media composition can lead to morphological similarities between cultures of $M$. laxa and $M$. fructicola isolates from New York (personal observation). Given that the discovery of M. polystroma and other species, such as M. mumecola and M. yunnanensis, was only made possible by molecular-based diagnostic tools, the use of one or more molecular methods for species differentiation should be of paramount importance. Although numerous polymerase chain reaction (PCR)-based methodologies for identifying and differentiating Monilinia species are available, no single method is documented as being able to differentiate among the principal species causing brown rot: M. polystroma, M. fructicola, M. fructigena, M. laxa, M. mumecola, and M. yunnanensis. Presently, it would be essential to use one method that identifies a genotype associated with $M$. polystroma and another method that would rule out the genotypes associated with the remaining species. For example, one could use the simple rDNA PCR restriction fragment length polymorphism (RFLP) assay described by Vasić at al. (2016), which consistently identifies a genotype possessed by $M$. polystroma and not by $M$. fructicola, $M$. fructigena, and M. laxa. If one was still concerned that M. polystroma could produce an rDNA PCR-RFLP genotype similar to that of M. mumecola or M. yunnanensis, one could subsequently utilize the method described by $\mathrm{Hu}$ et al. (2011) to rule out those species. More specifically, a diagnostician could perform PCR or PCR with sequencing to confirm that the genotype of the cytochrome b (cyt b) gene for the putative M. polystroma did not match those for M. mumecola or M. yunnanensis. Based on the magnitude of differences in the DNA sequence of $c y t b$ between the other five key species, it is reasonable to hypothesize that $M$. polystroma would produce a similarly different $c y t b$ genotype. If uncertainties remained, additional confirmation could be obtained by performing a bioinformatics panel using PCR melting profile, inter-simple sequence repeat markers, or random amplification of polymorphic DNAs as described by Poniatowska et al. (2016). Between the in-depth information on species morphology and the availability of several molecular tools capable of identifying species-specific genotypes at several loci, diagnosticians should have a high level of confidence in correctly identifying putative $M$. polystroma isolates.

\section{Mitigation and Disease Management}

In stone fruit, M. polystroma causes blossom blight, shoot blight, and brown rot of both green and mature fruit in a manner identical to that of other Monilinia species. In terms of its ability to cause disease, $M$. polystroma is most similar to M. fructigena, one of the most prevalent species causing brown rot in Europe. In some instances, M. polystroma has been found to be slightly less aggressive than M. fructigena in regard to lesion expansion on apples (van Leeuwen et al. 2002a; Vasić at al. 2016). In turn, $M$. fructigena is considered to be less virulent and aggressive than M. laxa and M. fructicola, which are native to North America (Jones and Aldwinckle 1990; Sullivan 2013). Hence, M. polystroma may likely be managed with the same horticultural practices and chemical management programs as M. laxa and M. fructicola. There are examples, however, of species-specific responses to fungicide selection pressure. For example, species of the closely related fungus Botrytis respond differently to fungicide selection pressures (Plesken et al. 2015). In comparison to North American Monilinia species, $M$. polystroma is probably most similar to $M$. laxa owing to its propensity to cause shoot and blossom blight and its preferential growth at $22^{\circ} \mathrm{C}$. In North America, management of $M$. polystroma should consider early season management practices to prevent blossom and shoot blight. At the same time, M. polystroma is more often isolated from fruit than blossoms, and efforts should primarily focus on preharvest management.

Management of brown rot in stone fruit begins in the fall and winter with the removal or burial of mummified fruit from the orchard floor and on trees. Such practices 
can greatly reduce the amount of overwintering inoculum and subsequent infections in the following spring (Holb and Scherm 2007). Inoculum removal, however, may be impractical for larger operations ( $>10$ acres) where availability of sufficient postharvest labor is limited. Over the winter months, pruning of dead or older unproductive shoots, which may serve as a source of overwintering mummy and canker inoculum, can also reduce the incidence of brown rot infections the following spring (van Leeuwen et al. 2002b). At bud break in the spring, delayed dormant applications of fixed copper fungicides to prevent peach leaf curl or early season bacterial diseases may further reduce overwintering canker inoculum that would begin to sporulate with the onset of warm weather. Such practices have been shown to be beneficial for other fungal diseases as a means of reducing the inoculum levels of fungicide-resistant strains (Frederick et al. 2015). In addition to cultural and chemical sanitation, producers should rely on chemical management programs for brown rot control. Such programs begin at bloom to protect young susceptible shoots and flowers. Fungicides are typically applied protectively at 10- to 14-day intervals, prior to rain events, when temperatures are greater than $60^{\circ} \mathrm{F}$. Multisite protectant fungicides, such as chlorothalonil, are used from bloom to petal fall and shuck split or shuck off to prevent blossom blight, shoot blight, and immature fruit infections. Chlorothalonil is a multisite protectant fungicide that is highly effective against brown rot but has a limited application window on stone fruit. Applications of chlorothalonil are prohibited after shuck split, when the green fruit are fully exposed. Similarly, iprodione is a single-site fungicide that is also highly effective in preventing early season brown rot but has the same limited use pattern as chlorothalonil. Because of the effectiveness and limited use window for chlorothalonil and iprodione, these two fungicides have become the mainstay of early season brown rot management programs in the northeastern United States. During this same timeframe, the anilinopyrimidine (AP) fungicides cyprodinil and pyrimethanil are also used owing to increased activity in cold weather and to ensure fungicide resistance management through chemistry rotation. Sulfur and captan, two other multisite protectant fungicides, are also viable options for early season brown rot management, but some stone fruit species such as cherries are prone to injury by sulfur and captan.

Although chlorothalonil is often used for early season brown rot control, it is often not as effective against $M$. laxa, which causes an aggressive blossom and shoot blight in cherries and apricots. Isolates of M. laxa from New York have been found to be more sensitive to demethylation inhibitor (DMI) and quinone outside inhibitor (QoI) fungicides than isolates of $M$. fructicola, even from the same orchard and tree (Hily et al. 2011) (Fig. 8B). Therefore, other species with the propensity to cause blossom blight and shoot blight, such as $M$. polystroma, may be more effectively managed with an application of single-site fungicides during bloom or early shoot elongation.

As fruit develop, they are fairly susceptible to brown rot infections until pit hardening, and so fungicide applications should continue at 10- to 14-day intervals. After pit hardening, there is a brief period when fruit are less susceptible to brown rot, but this period ends as fruit mature and accumulate sugars in the mesocarp and harvest approaches. During this preharvest period, single-site fungicides belonging to the DMI, QoI, and succinate dehydrogenase inhibitor (SDHI) classes are applied in rotation on 10- to 14-day intervals. Although there have been reports of DMI resistance and reduced sensitivity to QoI fungicides in populations of $M$. fructicola in the eastern United States (Burnett et al. 2010; Villani and Cox 2011), increased labeled rates of DMI fungicides and fungicide class rotation have ensured that DMIs and QoIs remain in preharvest chemical management programs. In the last 5 years, several fungicide premix products composed of DMIs mixed with APs, QoIs mixed with SDHIs, and other combinations have been registered for brown rot management in stone fruit. Of these products, premixed or single fungicide products containing the DMI fungicide difenoconazole, the QoI fungicide pyraclostrobin, and the SDHI fungicides fluopyram, penthiopyrad, and fluxapyroxad have been shown to be highly effective against $M$. 
fructicola preharvest (McFarland and Lalancette 2012; Ritchie and Smith 2012) (Fig. $8 \mathrm{~A})$. Although such premixed products are highly effective against brown rot and mitigate concerns of fungicide resistance, they present complications when trying to take into account the maximum number of allowed uses for each chemical class when fungicide product rotations are practiced.

Once fruit are harvested, they may be treated with drenches containing fungicides such as fludioxonil or pyrimethanil, which are registered for postharvest use in stone fruit in the United States. The practice of fungicide drenches in stone fruit is not common in many operations in Europe but is fairly common in large regional fruit packinghouses in North America, particularly in the peach production regions in the southeastern United States. Postharvest fungicide use is not allowed on stone fruit in the European Union (Karabulut and Baykal 2004). The lack of postharvest fungicide use could increase the risk of transporting inoculum of M. polystroma, and other Monilinia species, on the surface of exported fruit. Aside from drenching, postharvest brown rot can be minimized by controlled atmosphere storage. Controlled atmosphere storage with low levels of oxygen and high levels of $\mathrm{CO}_{2}$ has been shown to minimize lesion development arising from latent brown rot infections in storage (Elmer et al. 2007; Holb et al. 2012; Tian et al. 2001). The level of $\mathrm{CO}_{2}$ needed to reduce postharvest brown fruit rot can vary by stone fruit crop and Monilinia species but typically ranges between 10 to $40 \%$. Preharvest calcium applications have also been shown to improve the overall effectiveness of controlled atmosphere storage in reducing the incidence of postharvest brown rot (Elmer et al. 2007; Holb et al. 2012; Tian et al. 2001).

As mentioned in the preceding sections, the development of brown rot of apples is fairly rare. It is especially rare in orchards managed with conventional fungicides. In North America, there have only been two cases of brown rot in apple of production relevance. These epidemics occurred in a single orchard in Pennsylvania and three orchards in Indiana in 2015 (Beckerman et al. 2016; Peter et al. 2015). In these orchards, brown fruit rot was observed following heavy rains near harvest when producers would
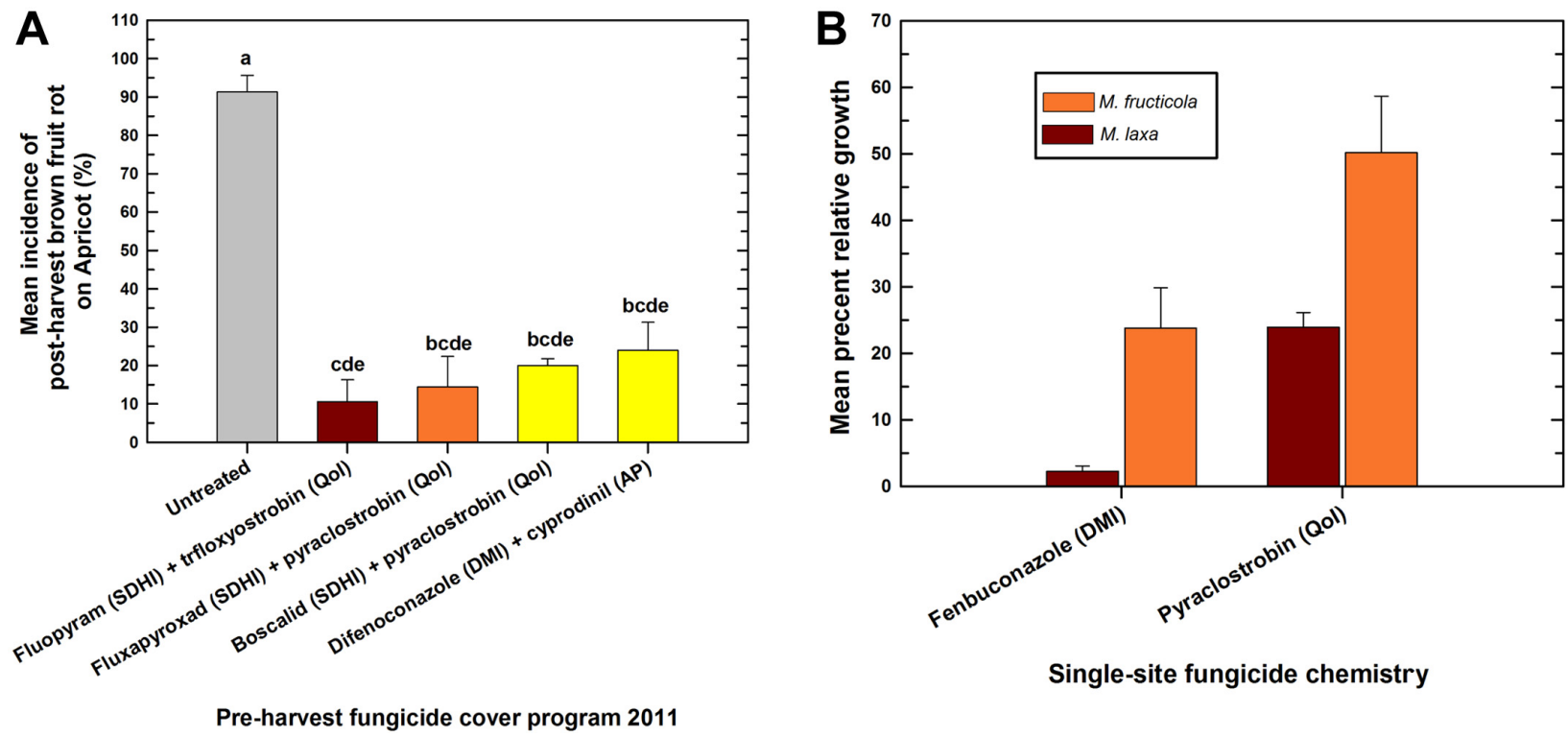

FIGURE 8

A, Effectiveness of single-site fungicides used in premixed products applied during preharvest fungicide cover programs to manage brown fruit rot in apricot in Geneva, NY, in 2011. Values represent the mean and standard error of fruit rot incidence for four replicate plots. Bars denoted by the same letter are not significantly different from one another $(\alpha=0.05)$. B, Difference in sensitivity to fenbuconazole (demethylation inhibitor, DMI) and pyraclostrobin (quinone outside inhibitor, Qol) between isolates of Monilinia fructicola and M. laxa collected from the same stone fruit orchards in New York from 2008 to 2011. Values represent the means and standard errors for $>33$ isolates. 
have the most difficulty maintaining fungicide coverage and preventing injury to nearly ripe fruit. In Europe, brown rot of apple and pear caused by $M$. fructigena primarily occurs in production systems with reduced fungicide applications or in organic orchards, which rely on biological control or applications of less effective fungicides such as sulfur and copper (Holb 2004; Holb and Scherm 2008). To manage brown rot in organic production systems, producers should practice inoculum reduction in the fall and winter (Holb and Scherm 2008) and maintain short intervals for organic-approved fungicides over the summer months until harvest. In pome fruit orchards managed with conventional fungicides, summer covers could be made at longer 14- to 21-day intervals but should include single-site fungicides that are known to be effective against brown rot (e.g., difenoconazole, pyraclostrobin, fluopyram, and fluxapyroxad).

\section{Economic Impact}

Monilinia polystroma is capable of causing blossom blight, shoot blight, and fruit rot in stone and pome fruit, which are abundantly planted in North America. And although there is potential for economic loss in North America from this invasive species, it may not have a substantial impact on stone or pome fruit production. M. polystroma is considered to be less aggressive than $M$. fructigena and may have a difficult time competing against the highly aggressive endemic North American populations of M. laxa and M. fructicola. In the northeastern United States, M. polystroma would have further difficulties competing with populations of M. fructicola that have some quantitative level of resistance to DMI and QoI fungicides (Hily et al. 2011; Villani and Cox 2011). If isolates of $M$. polystroma were imported, they would likely come from organic apple production operations, where the incidence of brown rot and inoculum pressure are the highest (Holb 2004; Holb and Scherm 2008). Such isolates would be fairly sensitive to the single-site fungicides available in North America because they are not allowed in organic production or potentially prohibited for use in conventional orchards in Europe. In this regard, DMI and QoI resistant isolates of $M$. fructicola would be positioned to easily outcompete $M$. polystroma, because there have been no reports of resistance to any fungicide class in M. polystroma. By comparison, North American populations of M. laxa are much more sensitive to DMI and QoI fungicides (Hily et al. 2011) (Fig. 8B). Where DMI and QoI sensitive populations of M. fructicola are present, such as in organic production operations, M. polystroma may better compete with $M$. fructicola on fruit, particularly in colder production regions and in postharvest storage.

Although the two endemic North American species, M. laxa and M. fructicola, can cause devastating outbreaks of blossom blight, shoot blight, and fruit rot during wet seasons when fungicide coverage is compromised, production losses from M. laxa and $M$. fructicola are typically fairly low. When control failures were reported for orchards with DMI-resistant populations of M. fructicola in New York from 2005 to 2009, the incidence of brown fruit rot rarely exceeded 5\% (Villani and Cox 2011). In subsequent seasons, there have been few or no reports of brown fruit rot control failures made known to the authors of that report and this current document. In 2008 to 2011, outbreaks of blossom and shoot blight, caused by M. laxa, did occur in New York. During these historically uncharacteristic wet springs, the incidence of shoot blight did not exceed $15 \%$ on first-year shoots, and it had little to no impact on brown fruit rot development at harvest (Cox and Villani 2010; Cox et al. 2011). In subsequent years, and for the 10 years preceding 2008, neither severe outbreaks of shoot blight and blossom blight nor M. laxa have been reported in stone fruit in New York and the New England states. In Poland, where M. polystroma is present, surveys of cherry orchards from 2010 to 2013 revealed that only 3 of 46 orchards were affected by M. polystroma (Poniatowska et al. 2016). Considering the sporadic occurrence of $M$. polystroma in countries where the pathogen is routinely detected, and the magnitude and frequency of brown rot epidemics of economic importance in eastern North America, it is unlikely 
that the additional presence of $M$. polystroma would have a substantial additional effect on the overall economic impact of brown rot of stone fruit.

In apples and pears, brown fruit rot epidemics rarely occur in eastern North America. As mentioned in the previous section, there have only been two outbreaks of economic concern in the eastern United States. These occurred at three orchards in Indiana and one orchard in Pennsylvania in 2015 and were likely owing to the presence of nearby stone fruit plantings with brown fruit rot and heavy rains at harvest (Beckerman et al. 2016; Peter et al. 2015). In Europe, brown rot of apple caused by M. fructigena rarely causes disease in orchards managed with conventional fungicides, and when outbreaks have been reported, the incidence of brown rot was less than $5 \%$ (van Leeuwen et al. 2000; Xu and Robinson 2000). In organic orchards or operations with limited fungicide inputs, incidents of brown rot of pome fruit can be much more devastating, approaching 50\% (Holb 2004; Holb and Scherm 2008). If M. polystroma did become established in eastern North America, it would likely pose the greatest threat to organic production operations. In pome fruit orchards managed with conventional fungicides, standard summer fungicide programs for the management of other similar preharvest fruit rot diseases would likely eliminate M. polystroma.

\section{Response}

As discussed in previous sections, Monilinia species capable of causing blossom blight, shoot blight, and fruit rot are endemic to North America but have limited economic impact when orchards are properly managed. Similarly, a few different $M o$ nilinia species in Europe are capable of causing the disease on stone fruit and apple, and the presence of $M$. polystroma does not appear to pose any additional management problems or challenges in the affected countries (Poniatowska et al. 2016; Vasić et al. 2016). In this regard, M. polystroma also does not appear to pose any additional disease management challenges to the stone and pome fruit industries in North America. There is a possibility, however, that certain stone fruit and pome fruit varieties planted in North American could possess some yet unknown susceptibility to $M$. polystroma. Certainly, developing fruit spurs of Ashton Bitter apples in Hungary became blighted and developed stromata of M. polystroma (Petróczy and Palkovics 2009). Because of this possibility, a rigorous response is needed to prevent the entry of this species to North America or its spread if it is introduced.

The response envisioned by the authors begins with import regulations, inspection, and quarantine of stone fruit and apple propagation materials from countries where $M$. polystroma has been detected. All imported budwood and shoot samples with obvious cankers and fruit mummies should be rejected and eradicated at the point of entry. Similarly, imports of fresh market fruit from countries where M. polystroma has been detected should also be inspected for brown fruit rot, and shipments should be rejected if any sporulating brown rot lesions are detected, irrespective of the species identified. Should imported propagation material pass inspection, it should undergo field certification until the end of the first fruiting year. During certification, the plants should be placed under a chemical program consisting of rotations among single-site fungicides of different classes (i.e., DMIs, QoIs, APs, and SDHIs). A standard program of protectant fungicides would be initiated at bloom and include at least one single-site fungicide application before shuck split or shuck off. This chemical management program would continue until fall or harvest, with two to four single-site fungicide applications of DMIs, QoIs, APs, and SDHIs in rotation. After harvest, fruit mummies should be removed, and should brown rot develop, a minimum of 12 disease tissue (fruit, flowers, or shoot) samples per acre should be subject to morphological and molecular identification of species. Following the first fruiting year, material could be released for propagation or production provided that M. polystroma was not detected. 
Although the research on M. polystroma has not been as extensive as other species, considerable research has been conducted on the pathology, epidemiology, and management of brown rot and Monilinia species in general. Given the similarities between M. polystroma and endemic species, there are few barriers to our understanding and management of this new species. It would be important, however, to evaluate several of the newer molecular methods for species identification against a wide collection of Monilinia species. Many of the existing PCR methods for species identification exclude one or more of the recently discovered species such as M. polystroma, M. yunnanensis, and M. mumecola. Reoptimization of existing molecular methods may lead to a more definitive test for differentiating Monilinia species. Aside from improved diagnostic methods, it is essential to learn more about the inherent sensitivity of M. polystroma to many of the key single-site fungicide classes registered for brown rot management in North America. Given that fungicide sensitivity has been known to differ among species of Monilinia (Hily et al. 2011) (Fig. 8B), such work is critical for identifying the best fungicides to manage M. polystroma. Along these lines, it would also be important for stone fruit breeders to include invasive Monilinia species in their screen for disease susceptibility. Unfortunately, regulatory restrictions for invasive species would present challenges to conducting such studies in the United States, where the fungicides and breeding selections are readily available. In turn, the availability of invasive Monilinia species in Europe but not the broad range of fungicides and breeding materials would present similar challenges. Aside from these two priorities, the existing research and the available extension resources on brown rot and M. polystroma are more than adequate to meet the challenges this species currently represents.

\section{ACKNOWLEDGMENTS}

We acknowledge the funding support from the National Plant Disease Recovery System (NPDRS) of the USDA-Office of Pest Management Policy. We thank Michael Wisniewski (USDA-ARS Appalachian Fruit Research Station) for his review of a near final draft of this manuscript.

\section{References}

Anonymous. 2011. First report of Monilia polystroma in Czech Republic. EPPO Reporting Service 2011/134.

Anonymous. 2016a. Fresh Deciduous Fruit: World Markets and Trade (Apples, Grapes, \& Pears). U.S. Department of Agriculture Foreign Agricultural Service. http:// apps.fas.usda.gov/gats/default.aspx

Anonymous. 2016b. Fresh Peaches and Cherries: World Markets and Trade. U.S. Department of Agriculture Foreign Agricultural Service. http://apps.fas.usda.gov/gats/ default.aspx

Beckerman, J., Albright, N., and Abbott, C. 2016. First report of brown rot (Monilinia fructicola) on apple (Malus $\times$ domestica). Plant Dis. 100:1949.

Burnett, A., Lalancette, N., and McFarland, K. 2010. First report of the peach brown rot fungus Monilinia fructicola resistant to demethylation inhibitor fungicides in New Jersey. Plant Dis. 94:126.

Cline, E. T., and Farr, D. F. 2006. Synopsis of fungi listed as regulated plant pests by the USDA Animal and Plant Health Inspection Service: Notes on nomenclature, disease, plant hosts, and geographic distribution. Online. Plant Health Prog. doi: 10.1094/PHP2006-0505-01-DG.

Cox, K. D., and Villani, S. M. 2010. Confirmation of European brown rot caused by Monilinia laxa on tart cherry, Prunus cerasus, in Western New York. Plant Dis. 94:783.

Cox, K. D., Villani, S. M., Raes, J. J., Freier, J., Faubert, H., Cooley, D., and Clements, J. 2011. First reports of brown fruit rot on sweet cherry (Prunus avium) and plum (Prunus domestica), and shoot blight on apricot (Prunus armeniaca), kwanzan cherry (Prunus serrulata) and sweet cherry (Prunus avium) caused by Monilinia laxa in New York, Rhode Island, and Massachusetts. Plant Dis. 95:1584. 
De Cal, A., and Melgarejo, P. 1999. Effects of long-wave UV light on Monilinia growth and identification of species. Plant Dis. 83:62-65.

Di Francesco, A., Fruk, M., Martini, C., Jemric, T., and Mari, M. 2015. First report of Asiatic brown rot (Monilinia polystroma) on apple in Croatia. Plant Dis. 99:1181.

Elmer, P. A. G., Spiers, T. M., and Wood, P. N. 2007. Effects of pre-harvest foliar calcium sprays on fruit calcium levels and brown rot of peaches. Crop Prot. 26:11-18.

Frederick, Z. A., Villani, S. M., and Cox, K. D. 2015. The effect of delayed-dormant chemical treatments on demethylation inhibitor (DMI) sensitivity in a DMI-resistant population of Venturia inaequalis. Plant Dis. 99:1751-1756.

Fulton, C. E., van Leeuwen, G. C. M., and Brown, A. E. 1999. Genetic variation among and within Monilinia species causing brown rot of stone and pome fruits. Eur. J. Plant Pathol. 105:495-500.

Harada Y. 1977. Studies on the Japanese species of Monilinia (Sclerotiniaceae). Bull. Fac. Agric., Hirosaki Univ. 27:30-109.

Hilber-Bodmer, M., Knorst, V., Smits, T. H. M., and Patocchi, A. 2012. First report of Asian brown rot caused by Monilia polystroma on apricot in Switzerland. Plant Dis. 96:146.

Hily, J.-M., Singer, S. D., Villani, S. M., and Cox, K. D. 2011. Characterization of the cytochrome $\mathrm{b}($ cyt $b)$ gene from Monilinia species causing brown rot of stone and pome fruit and its significance in the development of QoI resistance. Pest. Manag. Sci. 67:385-396.

Holb, I. 2004. Yield loss and disease development of Monilinia fructigena (Aderh. \& Ruhl.) honey in an organic apple orchard. J. Agric. Sci. 15:519-528.

Holb, I. J., Balla, B., Vámos A., and Gáll, J. M. 2012. Influence of preharvest calcium applications, fruit injury, and storage atmospheres on postharvest brown rot of apple. Postharvest Bio. Technol. 67:29-36.

Holb, I. J., and Scherm, H. 2007. Temporal dynamics of brown rot in different apple management systems and importance of dropped fruit for disease development. Phytopathology 97:1104-1111.

Holb, I. J., and Scherm, H. 2008. Quantitative relationships between different injury factors and development of brown rot caused by Monilinia fructigena in integrated and organic apple orchards. Phytopathology 98:79-86.

Hu, M.-J., Cox, K. D., Schnabel, G., and Luo, C. X. 2011. Monilinia species causing brown rot of peach in China. PLoS ONE 6(9):e24990. doi: 10.1371/journal.pone. 0024990

Johnston, P., Seifert, K. A., Stone, J., Rossman, A. Y., and Marvanova, L. 2014. Recommendations on generic names competing for use in Leotiomycetes (Ascomycota). IMA Fungus 5:91-120.

Jones, A. L., and Aldwinckle, H. S., eds. 1990. Brown rot diseases. Page 32 in: Compendium of Apple and Pear Diseases. APS Press, St. Paul, MN.

Karabulut, O. A., and Baykal, N. 2004. Integrated control of postharvest diseases of peaches with a yeast antagonist, hot water and modified atmosphere packaging. Crop Prot. 23:431-425.

Lack, K. J. 1989. The spread of apple brown rot (Monilinia fructigena) by insects. Ann. App. Biol. 115:221-227.

Lane, C. R. 2003. A synoptic key for differentiation of Monilinia fructicola, M. fructigena, and M. laxa, based on examination of cultural characters. EPPO Bull. 32:489-493.

Luo, Y., and Michailides, T. J. 2001. Factors affecting latent infection of prune fruit by Monilinia fructicola. Phytopathology 91:864-872.

Luo, Y., Michailides, T. J., Morgan, D. P., Krueger, W. H., and Buchner, R. P. 2005. Inoculum dynamics, fruit infection, and development of brown rot in prune orchards in California. Phytopathology 95:1132-1136.

Martini, C., Lantos, A., Di Francesco, A., Guidareli, M., D’Aquino, S., and Baraldi, E. 2014. First report of Asiatic brown rot caused by Monilinia polystroma on peach in Italy. Plant Dis. 98:1585.

McFarland, K. A., and Lalancette, N. 2012. Management of peach brown rot blossom blight and fruit rot, 2011. Plant Dis. Manag. Rep. 6:STF010.

Munda, A. 2015. First report of brown rot on peach caused by Monilia polystroma in Slovenia. Plant Dis. 99:1281.

Ogawa, J. M., and English, H. 1991. Diseases of Temperate Zone Tree Fruit and Nut Crops. Publication 3345. University of California, Division of Agricultural and Natural Resources, Oakland, CA.

Peter, K. A., Gaskins, L., Lehman, B., and Jurick, II, W. M. 2015. First report of brown rot on apple fruit caused by Monilinia fructicola in Pennsylvania. Plant Dis. 99:1179.

Petróczy, M., and Palkovics, L. 2009. First report of Monilia polystroma on apple in Hungary. Eur. J. Plant Pathol. 125:343-347.

Plesken, C., Weber, R. W. S., Rupp, S., Leroch, M., and Hahn, M. 2015. Botrytis pseudocinerea is a significant pathogen of several crop plants but susceptible to displacement by fungicide-resistant B. cinerea strains. App. Environ. Microbiol. 81:7048-7056. 
Poniatowska, A., Michalecka, M., and Puławska, J. 2016. Genetic diversity and pathogenicity of Monilinia polystroma-The new pathogen of cherries. Plant Pathol. 65:723-733.

Ritchie, D. F., and Smith, A. M. 2012. Efficacy of pre-mixed fungicides for fruit rot control of peaches, 2011. Plant Dis. Manag. Rep. 6:STF015.

Sullivan, M. 2013. CPHST Pest Datasheet for Monilia polystroma. USDA-APHIS-PPQCPHST, Raleigh, NC.

Tian, S., Fan, Q., Xu, Y., Wang, Y., and Jiang, A. 2001. Evaluation of the use of high $\mathrm{CO}_{2}$ concentrations and cold storage to control of Monilinia fructicola on sweet cherries. Postharvest Biol. Technol. 22:53-60.

USDA National Agricultural Statistic Service. 2016. Noncitrus Fruits and Nuts 2015 Summary. National Agricultural Statistics Service, Washington, DC.

van Leeuwen, G. C. M., and van Kesteren, H. A. 1998. Delineation of the three brown rot fungi of fruit crops (Monilinia spp.) on the basis of quantitative characteristics. Can. J. Bot. 76:2042-2050.

van Leeuwen, G. C. M., Baayen, R. P., Holb, I. J., and Jeger, M. J. 2002a. Distinction of the Asiatic brown rot fungus Monilia polystroma sp. nov. from M. fructigena. Mycolog. Res. 106:444-451.

van Leeuwen, G. C. M., Holb, I. J., and Jeger, M. J. 2002b. Factors affecting mummification and sporulation of pome fruit infected by Monilinia fructigena in Dutch orchards. Plant Pathol. 51:787-793.

van Leeuwen, G. C. M., Stein, A., Holb, I. J., and Jeger, M. J. 2000. Yield loss in apple caused by Monilinia fructigena (Aderh. \& Ruhl.) honey, and spatio-temporal dynamics of disease development. Eur. J. Plant Pathol. 106:519-528.

Vasic, M., Duduk, N., and Isovanik, M. S. 2013. First report of brown rot caused by Monilia polystroma on apple in Serbia. Plant Dis. 97:145.

Vasić, M., Duduk, N., Vico, I., Rančić, D., Pajić, V., and Backhouse, D. 2016. Comparative study of Monilinia fructigena and Monilia polystroma on morphological features, RFLP analysis, pathogenicity and histopathology. Eur. J. Plant Pathol. 144:15-30.

Villani, S. M., and Cox, K. D. 2011. Characterizing fenbuconazole and propiconazole sensitivity and the prevalence of 'Mona' in isolates of Monilinia fructicola from New York. Plant Dis. 95:828-834.

$\mathrm{Xu}, \mathrm{X}$. M., and Robinson, J. D. 2000. Epidemiology of brown rot (Monilinia fructigena) on apple: Infection of fruits by conidia. Plant Pathol. 49:201-206.

Zhu, X. Q., and Guo, L.Y. 2010. First report of brown rot on plum caused by Monilia polystroma in China. Plant Dis. 94:478. 